Logos Universality Mentality Education Novelty, Section: Social Sciences

ISSN: $2284-5747$ (print), ISSN: $2284-5747$

(electronic)

Covered in: CEEOL, Index Copernicus, Ideas

RePeC, EconPapers, Socionet

\title{
POWER IN THE GREAT FEMININE EON: FEMININE VALUES OF POWER ACCORDING TO THE NEW TESTAMENT
}

\section{Mădălina Virginia ANTONESCU}

Logos Universality Mentality Education Novelty, Section:

Social Sciences, 2014, Year III, Issue 1, pp: 11-27

Published by:

Lumen Publishing House

On behalf of:

Lumen Research Center in Social and Humanistic Sciences 


\title{
Power in the Great Feminine Eon: Feminine Values of Power According to the New Testament ${ }^{1}$
}

\author{
Mădălina Virginia ANTONESCU²
}

\begin{abstract}
During history, basic concepts for understanding the patterns of buman society, the way of conceiving and practicing policy or perceiving authority have received meanings affected (even distorted) by gender history. Thus, it happened a rigorous separation (from conceptual, academic level to practice) of these concepts (power, authority) from feminine universe and from all things associated with woman and feminine. Despite the fact that they are feminine nouns (in Romanian language), the power and authority contents were dissociated from any link with feminine universe, capable to offer a respected status, high social position, prestige, value and respect for each woman. Used in a patriarchal meaning, deeply disregarding and even denying woman and feminine attributes, these concepts became cultural tools for oppressing women in societies organized on the criterion of "natural" association between masculine and power/authority. The methodology used in the present study is based on a gender analysis of power and authority concepts, inclusively by approaching theological perspective, mixed with elements of futurology and theory of civilization.
\end{abstract}

\section{Keywords:}

Women's rights, gender studies, authority, patriarchal system, feminine power

\footnotetext{
1 Theo-politics article (the study of political science via religious factor), containing futurology elements, the dynamics of human organizing systems and gender studies. The paper is expressing only the author's personal point of view and it doesn't involve any other physical or legal person.

2 Scientific Researcher, Ph.D. in European Law, Faculty of Law, The University of Bucharest, Romania.
} 


\section{Introduction}

The Great Feminine Age, as a spiritual organizing pattern of the Earth's spiritually highly-evolved civilizations in the 21 -st century will be structured on a spiritual basis (reconsidering woman's relationship to God seen as The Holy Spirit, not as "The Almighty Man" - the way the sacerdotal elites have credited Him for five millenniums in order to get and perpetuate the right to control and decide over human communities (societies).This re-evaluation refers to the woman seen as a buman being with divine spark, the same as man, as she is, by Christ's Law, "God's danghter", not a "servant", but equal to man, in the spirit of Christ's Law (all people are "arms of His Church", irrespective of rank, social status, origin, ethnic group, sex).

The societies of The Holy Spirit Eon ${ }^{6}$ recapture the ante-patriarchal experience of the civilizations based on feminist values, to which life-promoting sciences and arts are added to bonour the beauty and harmony of life, nature and mankind(in an attempt to encourage the alienated post- modern man not only to regain beauty as a feature of Divine Creation, but also to practice virtues, such as truth, good, justice, honesty, which have been excluded, disregarded during the patriarchal-imperial systems based on rituals of death, exploitation, alienation, destruction, robbery, manipulation, financial gambling and profit.

The Great Feminine Age will pay more attention to promoting the arts that can rediscover, teach and apply feminist values: love of mankind, love of nature, love of God, harmony, beauty and kindness, pity and devotion (female energy being lifegiving, hence worshipping through art the beauty, uniqueness and complexity of life, of God as life-giving, of the woman as creator, bearer and protector of life). These values of the Great Feminist Age should be presented and promoted to people through entirely different types of elites (sacred, political, cultural) from those employed by the old, discriminating, oppressive systems during the Long Patriarchal-Imperial Age. This does not mean that men will be discriminated or oppressed in the

3 Mihaela Miroiu, Gândul umbrei. Abordări feministe in filozofia contemporană, Ed. Alternative, București, 1995, pp. 31-32.

${ }^{4}$ According to the existing patriarchal statements up to the Apostles' Letters, i. e. even during the Christian Age, despite Christ's message of being united within the Church.

${ }^{5}$ Ioan, ch. 17:21. I Corinteni, ch. 12: 12-20, 25-27.

6 Again, the emphasis is on "God as the Holy Spirit", as Unborn Energy, inspiration, Almighty Being beyond human power and imagination, therefore, beyond man's obstinate cling to the patriarchal pattern of "God-Supreme Father" (the basis on which women have been exploited, cast away and disregarded in terrestrial societies for millenniums). God is "Spirit" and where there is the Holy Spirit, there is freedom. II Corinteni, ch. 3:17. "The Spirit is God" and those who worship Him, shall worship the spirit and truth. Ioan, ch. 4:24. We can notice that the Holy Spirit pattern is shown to people by Christ (exactly when He is talking about the Holy Spirit to...a woman). "The Spirit is the Life-giving One; the body is worthless, the Words I have told you are spirit and life". Ioan, ch. 6:63. 
Great Feminist Age. It means that they will be taught according to the values that protect and perpetuate life, not according to "values" that oppress, choke and destroy it (so, there will be a mental detachment from patriarchalism as a wrong perspective on mankind).

\section{From a dichotomist male/female perspective to a complementary, co- creative relationship, including politics}

In the balanced male/ female relationship, the latter is no longer associated with such symbols as death, robbery, exploitation, oppression, domination, egotism, profit. Man learns to be bimself again, that is, an equal partner to female energy, complementary to her, which is necessary to create, protect and promote life. Life is seen as a contribution of both types of energy, and man should learn to perceive himself as a loving male energy which protects life, not as an opposing one.

The Great Schism of Sexes, the Great female/male Division, supported and nourished throughout the millenniums in order to prevent the human being from attaining its true identity, its wholesome one-in which both energies co-operate in a holy reunion, i.e., closest to God as the Great Spirit, Holy Spirit, the Source of Life- is doomed to failure and will disappear during the Age of the Holy Spirit, after having set up and supported a millennium-long system of manipulation and control over people, prevention from reaching their genuine evolution towards the whole human being, in harmony with itself, with the two cosmicsacred(male and female), with the Earth, with the entire Holy Creation and with God.

The Age of the Holy Spirit is the Age of the Great Change, when people realize the negative effects (for the freedom of the human being, therefore, of the woman) of carrying on with the patriarchal-imperial system ${ }^{7}$.

It is an age of transition to alternative patterns of organizing buman societies, based on principles that have abandoned the patriarchal-imperial view on the world and mankind, on God Himself. The Absolute Father pattern, meaning The "Absolute Patriarch" whom people must obey without questioning and who is isolated from His Creation( hence, the schismatic way of living, according to the patriarchal-imperial pattern, i. e. being "at war" with one another, man with woman, man with God, Whom the former denies) becomes outdated.

This pattern is replaced by another, also present in the Holy Scripture (especially The New Testament, which brings a new perspective on God and His relationship with people, different from a biased, tyrannical, isolated, spiteful and angry God, who persists in the Old Testament and who was seen

\footnotetext{
${ }^{7}$ David C. Korten, Marea Cotitură. De la imperiu la comunitatea terestră, trad. Mihnea Columbeanu, Ed. Antet, Prahova, 2007, pp. 23-27.
} 
as a model for organizing human societies, prior to the birth of Christianity, based on the Old Testament).

This pattern different from "The Absolute Patriarch" (from which stems the legality of the behavioural, axiological and social pattern of male elite, especially towards the status of the woman in society, religion, culture, politics, economy) is also called the pattern of "God as Life-creating Spirit" , namely, a transcending God, above the material, thus above any attempts of separating and discriminating between male and female. This type of pattern, present in the New Testament, was promoted by Christ, as the key-word of His message of universal love amongst all people, irrespective of gender, wealth, origin, rank and other operating criteria within the societies based on the opposed pattern (patriarchal-imperial).

The pattern of "God-Life-creating Spirit" (which sends us again to the Third Hypostasis of the Holy Three, to the Holy Spirit and Its womanly aspect, continually ignored by the Clergy and the Male Sacerdotal Elites when interpreting the New Testament ${ }^{10}$ ) suggests a type of non-sexual relationship between man and God (above the male/female difference among people, as a gender paradigm that would enable some- men, here- to transcend whereas others would be excluded- women, here- practically dooming a whole sex to remain at the material level). There is a non-sexual, sacred universal love to which all people can belong and where all people can cherish God's presence.

Christ, both as God and man, best explained to people the inefficiency of dichotomist way of thinking, denying the tense, hostile relationship- leading to ontological hatred- between men and women (supported and...legalized by the pattern of "Absolute Father", "Supreme Patriarch" due to the elites who promoted the patriarchal-imperial pattern). He insisted on a respectful, loving (agape),trusting attitude of man towards woman, on understanding the deep connection between men and women (one through the other towards perfection $)^{11}$ contrary to an obeying, hierarchic, schismatic relationship between them, as imposed by the opposite pattern, patriarchal-imperial.

Christ also showed people how they should interpret God's Being as his fatherly appearance (God the Father as a loving, caring, generous parent, not as a discriminating, spiteful, angry and isolated tyrant). He uses in the parable of the squandering son the image of the Forgiving Father, Who welcomes his son,

\footnotetext{
${ }^{8}$ David Korten, op. cit., pp. 217-218.

9 "The spirit is God and those who worship Him, shall worship the spirit and truth(Ioan, ch. $4: 24)$ or "God is the spirit and wherever is God's Spirit, there is freedom" (II Corinteni, ch. 3:17-18).

${ }^{10}$ Overlooked pattern, including the perspective of the perpetuation need, by these elites, of the old patriarchal-imperial pattern.

${ }^{11}$ II Corinteni, ch.3:18, Galateni, ch. 3:26-28, ch. 4:4-7, Efeseni, ch 4:24, I Corinteni, ch. 11:11.
} 
despite the latter's mistakes and estrangement (equal to an entire behavioural and mental pattern of the postmodern, alienated people.

The latter pattern, which is the basis of the Great Feminist Age, re-sets the Spirit in the center of attention and establishes the foundation for building new patterns of post-patriarchal-imperial human societies.

The Spirit is wise, caring mother, healing and comforting, associated with sympathy, with love shared with everyone, and the spiritual conscience is the bighest level of human conscience ${ }^{12}$, which connects the human being direct with God, as the Omnipresent Being, as the Source of Life.

In the Eon of the Great Feminine Governance ${ }^{13}$, man will analytically bring back the past in order to recall the lessons of his millennium-long history of patriarchal rule and learn from them.

So, the Long Row of Dark. Ages have been governed by the pattern of separation between sexes, which made it impossible to achieve a genuine union as far as the human being is concerned as well as the relationships among people and human communities on the whole. During this patriarchal age the notions of "male energy" and "female energy", energies that co-exist in a harmonious and complementary way have been reversed and applied differently (in a distorted way from their true nature and usage). But on this planet of endless suffering arisen from the never-ending cycle of all kinds of separations ("the planet of separations" becoming in this way a genuine spiritual and mental human prison) for millenniums, in the patriarchal age, the distorted understanding and practice of the notions of "female energy" and "male energy" have made it possible not only the appearance, consolidation and expansion (in time and space), but also the destruction of systems and civilizations founded on these distorted patterns of perceiving these two energies.

Accordingly, during the patriarchal age (which was over, now Mother's Eon ${ }^{14}$ having already begun, that of the Holy Spirit) the "buman" civilization (if we wrongly call it like that, compared to the distorted energies by the patriarchal rule) was the product of:

- a distorted perception and practice of male energy: it was understood as a deadly, destructive energy based on rituals of death, suffering, brutal force, conquest, violence (hailed as "heroism"), separation from female energy, feminist values and concerns. Male energy is turned against female energy, defined in terms of monopoly in a dictatorial, one-sided, distorted way, cast aside, or actually

${ }^{12}$ David Korten, op. cit., pg.250-251.

${ }^{13}$ Here, as a political and civilizational pattern based on feminine values, as an alternative model to the patriarchalism.

${ }^{14}$ By doing this, we do not lower the Holy Spirit to a limited and schismatic dimension of gender: we could be deceived similarly to the patriarchal pattern, by the reasoning: "if God is a man, then man is a god", for the other gender (woman) we reverse the roles (if God is a woman, then woman is a god, we would fall into a matriarchal trap). But God is Spirit and Spirit means doing away with any divisions and hierarchies (there is no hierarchy among The Three Persons of The Holy Three), it means love, peace and freedom. 
excluded from "human" civilization and history. The vicious male power is, therefore, thought to be: terror, cruelty and domination, the cult of negation, nothingness, death. Power, as seen by the patriarchal male, becomes the denial of being and living in a world of "female- intoxicated energies", which the male wants to totally destroy or, if this fails, to free himself from them, self-isolating in a Babel tower from Holy Creation, building in a blind, wicked attempt, a baseless shrine for his ego.

- a distorted understanding and practice of female energy: this was wrongly perceived as a second-hand energy (as it is... biofile) being arbitrarily given (by patriarchal elites who have managed the systems and civilizations of "human history" for five millenniums) an inferior, effaced status (together with feminine values and universe and the woman as a physical presence) meant to have little importance, slave, object-like being (when there were not obvious forms of exaggerated, clear separation at the system or civilization level).

\section{2. "Power": from the patriarchal meaning to a feminist regaining of the lost significance}

Regaining the power in the $3^{\text {rd }}$ millennium society, by women, uses the spiritual and religious dimension in its deep, genuine, Christian, wholesome meaning (in Christianity, here):

- People, by Christian law, are all "God's sons and daughters", not "slaves". If the rapport mankind - God fundamentally changes, then the traditional( patriarchal, millennium-long) man-woman one should also change (the woman is not the man's slave and she is not create to take of or to please the man, as hinted at or even openly imposed by systems during different historical periods built on the patriarchal-imperial pattern- claiming that it is "normal" or pointing out the female damnation due to..."the originar sin" or by "being created from the man's rib"). They exist "for each other", this is the right way of reading Christ's law.

- The woman is, by Christian law, "God's daughter", rejoicing in God's joy, as He is the Sovereign that invites people to enjoy His food together with $\mathrm{Him}^{17}$. The woman is not excluded, because she is a woman, from Heaven, which must be reached by "human striving ${ }^{18}$ to gain it through never-ending perfection of their lives by spiritual quest and discovery of "God - the Spirit", not by staying within the stiff patriarchal dogma of "God - the Absolute Master of

\footnotetext{
${ }^{15}$ Romani, ch. 13:10; I Corinteni, ch. 7:22; ch. 9:1; II Corinteni, ch. 3:17-18.

${ }^{16}$ I Corinteni, ch. 11:11; ch. 13:10,13; II Corinteni, ch. 3:17-18.

${ }^{17}$ Matthias, ch. 14:15-21.

${ }^{18}$ Matthias, ch. 11:12
} 
the woman, of mankind". God's Kingdom is an inner, spiritual one ${ }^{19}$, accessible to all those who strive to reach it, it cannot be seen or it does not function according to human logic (including that based on divided, patriarchal pattern).

- The legality and practice of Christian law operates for all people and their redemption, not only for men "God's sons", but also for women. Christ gives His life for all people, both men and women, not only for men (God is universal, total love, not exclusion and domination). Thus, neither can be accepted, nor tolerate any type of discriminating treatment of men and women in politics or society (from the Christian religious perspective) or within the Church: the is that whereas the Christians are told that they are "all God's children" 20 , by God's law, and all equal, as "members of the Church, women continue to be treated from patriarchal perspectives and practices. More exactly, they still face a lot of procedures and interdictions, some in full view, others implicitly allowed by the Church, or a series of beliefs and taboos according to the old law (the Old testament), which sees people as "God's slaves" and give women an inferior status, within the patriarchal system, denying the rise of mankind from death and sin by Christ's arrival as Messiah.

- Even worse, according to another perspective (dogmatic, stiff, away from the spirit of Christ's law which preaches total, universal love, without any discrimination as to sex, without ranking men and women through value) based on the New Testament (!) and according to patriarchal interpretation of what the Apostles ${ }^{21}$ said, referring to the woman status in the Church, society, woman is obviously ranked as inferior, if not excluded, so being doomed to silence $^{22}$. As a result, mankind parts with their full accomplishment (through each other, the female energy completing the male energy to achieve the exquisite, pure sacred union) by introducing a division in the very bosom of the Church and by misinterpreting the Christian message in a patriarchal, schismatic manner. That is why it was important that Christ's message be regained through fulfilling Christ's work, through exercising God's power of the Holy Spirit among people, that is why we should take into account the possibility of a feminine

${ }_{19}$ II Corinteni, ch. 3:17-18; Romans, ch. 14:17 (“God's Kingdom is not food and drink, but justice, peace and joy in the Holy Spirit").

20 The New Testament is very clear in this respect, demolishing the patriarchal mechanism of separation between sexes and their hierarchic ranking: "Love does not hurt those around it. Love is enforcing the law"). Romani, ch. 13: 8,10. This is also the deep meaning of the Arrival of another comforter, as Christ heralds. A feminine embodiment of the Holy Spirit, at the end of times, comes to complete Christ's work, to emphasize the Christian law of non-separation, of love among people, through the vision of the heavenly wedding (crowning the bride and groom as heavenly sovereigns) the woman rises to queenly honor, for all the Divine Creation and above herself( the woman is sanctified)

${ }^{21}$ Coloseni, ch. 3:18-19; Efeseni, ch. 5:22-24, 29 (associating the woman with the body, typically patriarchal), 33 ("woman's fear of man, which establishes the separation, hierarchy between sexes). I Corinteni, ch. 11:3, 7-12.

22 I Timotei, ch. 2:11-14. 
embodiment of the Holy Spirit on Earth. So, in the New Eon, through Christ's sacrifice and the completion of the Christian work by the Comforter, the Truth Spirit, the woman regains the two cosmic-divine rights: firstly, as "God's danghter,"23, secondly, being crowned and raised to queenly honour as life and light bearer and creator. Towards" the end of times" (moment mentioned in the Apocalypse, which still has not benefited from comprehensible theological comments for post- modernist buman) through female embodiment of the Holy Spirit, the woman becomes known to mankind in her inner self, beyond the traditional discriminating image, specific to the millennium-long image we have got used to, taking it for granted. The woman reveals herself as life-loving energy, life-protecting energy, life-giving and life-bearing energy, responsible for life growth and its protection.

- The traditional role that the woman has, to educate children ( to shape new generations), is actually a role of introducing them to civilization (unfortunately, now under the influence of the patriarchal pattern) of instilling the first moral values, the opposition good-bad, correct-incorrect (right-wrong), beautiful-ugly, the first notions of politeness, justice, a sense of beauty (generally, it is a highly complex endeavor with a civilizing purpose, known as "the seven years of home". This role changes, in the New Feminist Age, into an activity acknowledged by the political government (of a feminist type) as being the children's introduction to the principles of a civilization no longer following the patriarchal pattern, the separating and ranking way of seeing the world and the relationships between sexes. "The seven years of home" become a sustainable introduction to feminist influence on children as regards culture and civilization, governed by post-patriarchal methods.

- In the same way, educational and cultural fields turn into expression, dissemination and education patterns at a systematic level for the young generations, then for adults (in an endless exercise of reminding them of the feminist values and complementary relation male-female) in domains where feminist values are promoted, as well as the complementary relationships male-female, within the post-patriarchal civilizations. Feminizing the educational field is no longer disregarded, as in the patriarchal civilizations, it regains the glow it used to bave only in the societies based on partnership in prehistoric times, becoming the very promoting factor of feminist values and hindering the atypical function (for a feminist domain, such as education, irrespective of level or type, private-public) of being the promoter of patriarchal-imperial values when teaching people about the "normality" of discriminating, opposing and ranking relationships between man and woman.

- The woman is "the embodiment and likelihood of God",24, the same as man.

\footnotetext{
${ }^{23}$ Efeseni, ch. 5:2, 8; Galateni, ch. 4:4-7, ch. 5:6, 13.

${ }^{24}$ Credința Ortodoxă, Ed. Trinitas, Ed. Mitropoliei Moldovei şi Bucovinei, Iaşi, 2007, p. 62.
} 
- The principle of being complementary: "no woman without man, no man without woman, only one through the other" 25

- As "an exquisite being to worship God", the woman, as well as man, is "the embodiment and likelihood of God", so there is no ranking domineering-obeying relationship between the two divine faces, only face to face, i.e., opening $\mathrm{up}^{26}$, looking at the other and accepting them as they are, in their inner self; being complementary, both being enlightened (the human face turned towards God's Face) ${ }^{27}$

- "Fear of God" has no use in Christian law ${ }^{28}$, where there is no terror or fear of master, nor is any other additional fear born (woman's fear of man, "her master on this Earth"), but it should be interpreted as love and respect. Where there is love, there is neither fear ${ }^{29}$, nor domination (attitudes sprung from schism, fall of man and non-accomplishment).

- Fear leads to human rights violation, so it is not a feature (in its negative meaning) of Divine Creation, based on Prone (i.e. Almighty God's love and care for all His Creation). Here, the correct interpretation of the "fear of God" is self-limitation from destructive freedom (not from the creative, conscious and voluntary cooperation with God). Either do we refer to the sacred sphere (the speech about God, the interpretation of the Divine message, the Holy Being or God's power) or to the secular one (today's materialistic science, the evolution theory), we notice that both types (theo-centric or atheist) start from the millennium-long, historical reality that there is a monopoly, in both spheres, of an elite with patriarchal outlook, made up of, "obviously", men (even the few feminist exceptions who have succeeded in joining this elitist group play and define themselves in their patriarchal terms, not in terms of genuine feminist self, freed from this discriminating perspective). For these elites and for the established monopoly in both sacred and secular spheres for so long (till the patriarchal

\footnotetext{
${ }^{25}$ I Corinteni, ch. 11:11.

${ }^{26}$ II Corinteni, ch. 3:17-18.

${ }^{27}$ The Icon as Divine Face. See Vianu Mureşan, Simbolul. Icoana. Fața, Ed. Eikon, Cluj-Napoca, 2006, p. 131-141.

${ }^{28}$ We ought to mention the definition of tradition, as understood by the Orthodox Faith: 'tradition, in Christian belief, does not mean stuck in dead, human moulds, only unspoiled preservation of the truth about God's finding, endless source of accomplishment". Credinta Ortodoxă, op. cit., p. 35. So, we ought to do away with the patriarchal symbols, outlook and the traditional rituals (wedding, for instance) and replace them with a new symbolism, according to the Christian law. But, who should do it? Again, the male elite (theologists, priests or the high ranks of the Church, who are in charge of setting the basis of the new teaching and who is exclusively male)? Thus, they consider it a sacrilege to discuss the patriarchal aspects of the symbols, rituals, perspectives and interpretation of the Divine Christian message (which is not patriarchal) and we also include here the actively-defining feminist perspective.

${ }^{29}$ About love, as perfect and supreme power within the whole Divine Creation, see: I Corinteni, cap. 13:8, 13.
} 
pattern was misinterpreted as "normal" in the collective conscience) it is absurd that:

A woman should be in power unless a man has given it to her (and taken back), guaranteed by him (or by the male elite who is in control and makes decisions in that particular field, in which the woman wants to be promoted), or limited and controlled by him.

A woman should claim her power to come from God (given by God, Christ, The Holy Three, The Holy Father) as men-priests have claimed over the centuries. According to the narrow-minded patriarchal perspective, God is the model of "Absolute Master", of "Absolute Man" (hence the patriarchal belief "if God is a man, then the man becomes God for the woman). God is, in this perspective, manlike, created after the image and figure of the patriarchal man, of man-protector, man-judge (if you break his rules, then you dispute the male model of God in the Holy Three). Theological elites willingly and systematically ignore the fact that God is Spirit, uncreated Energy, Person in the Three Hypostasis and insist on the Absolute God-Man, misinterpreting the Christian law itself and parting from its spirit and meaning (God-Love, God-Spirit, God-Light pattern).

- Woman has inside the Light, the Divine Spark, so does man. This interpretation of the woman as sacred, brightly creative has been denied for centuries on end, reversing it, i.e., the woman may be linked (by her nature) with the dark demonic sphere of low vibration. The connection woman-light is, in patriarchal systems, a direct defiance to man power, since male, in schismatic, patriarchal perception, associated bimself with light, the sun, power, glamour, order. On the contrary, female is associated with darkness, chaos, disorder as well as weakness, inability, demon, deception, instinct (defined as opposed to or lack of reason).

- Christ's Church lives thanks to the Holy Spirit, He is Anima, the heart of the Church, i.e., He is the Bride, the soul of the Church, sacred, eternal and personal reality, not a metaphor.

The association between the woman and power, woman and God, woman and The Holy Spirit, woman and the supreme universal-divine power (respected and acknowledged in the entire Divine Creation, raised to the highest rank - as seen in the apocalyptic scene - the only cheerful moment of the Apocalypse - in "Wedding in Heaven", in which the bride and groom are crowned and wear lavish royal attire) is disturbing for the patriarchal elites, whichever they may be (secular or theological).The patriarchal order, far from being an illusion, is still real nowadays; this discriminating and hostile order towards woman and the possibility of a woman to possess power, not given or controlled by a man (in patriarchal order) has been under discussion, even more, it has been exposed as not genuinely buman and allowed by God.

This necessary activity of making public the existence of a patriarchal pattern in which people today (post-modernist people) live (consciously or 
unconsciously), of exposing it and destroying its hostile foundation, unfair to the woman (the Great division of Sexes) was achieved (after, so to say, "the First Breakage of the System", through Theotokos.

The patriarchal elite have defended their privileged position to define and impose a certain interpretation of the world, mankind and God Himself (in direct discord with the Christian law of non-differentiating). This elite, active even in an age when the woman has guaranteed rights at international, regional, national level, have tried to bold to a "unique", "genuinely buman" view which clearly discriminate women, especially regarding the sacred, their direct relationship with God. This direct relationship is not well seen by the theologians, who have built a huge logical and patriarchal discourse, starting from the assumption that man is not "woman's half", but "woman's master and ruler", thus changing the meaning of the Christian law of non-differentiating into a ranking and domineering one, which has nothing in common with God - The Holy Spirit.

God is Love, Spirit, Christ loves people and deserves to be loved by them, God does not mean fear and discriminating tyrannical rule, as the patriarchal have tried to suggest (or even impose such an interpretation in old times). People cannot limit God as to His decision, His embodiment, His work or plans.

Power has never been and is not a male monopoly; there is also a female power, literally, based on discovery of her own self (not presenting a false self, shaped after the patriarchal principles); there is a direct connection between the Holy Spirit and the female power ${ }^{30}$, rediscovered, original, not affected by patriarchal thinking, by the fall in the false human history. It is also proved that there are still unexplored meanings or not explored enough, even not known, of the term "power".

Power, unaltered by patriarchal pattern and its view based on violence, manipulation, lie, robbery, conquest, exploitation (by using male energy wrongly, far from its pure, bright essence) is the power resulted from being aware that the two energies (male and female) are pure, bright, complementary and life co-protective.

Power, in this unaltered meaning, is defined neither as brutal force, the law of the strongest or the most cunning, nor as domination or aggression, but it completely re-defines itself by re-evaluating its set of pure female and male values, not altered by the patriarchal order, re-found with their initial meaning, lost five millenniums ago.

\footnotetext{
${ }^{30}$ See feminist aspects of the Sacred, în Manfred Schmidt-Brabant, Isis-Sophia şi Marea Mamă, în Manfred Schmidt-Brabant, Virginia Sease, Femininul Arbetipal în curentul misterial al umanității, trad. Daniela Lazăr, Ed. Univers Enciclopedic Gold, Triade, Bucureşti, 2001, pp. 52-62.
} 
Genuine power is associated with Sophia, High Wisdom ${ }^{31}$, with reason, but also with justice, generosity and mercy (as the way the powerful relate to the others). Power, as meant by the Holy Spirit (its feminist self) and God's Mother is essentially the power of giving and protecting life; the power to heal, to comfort those in need and suffering, the power to dress the naked, to feed the hungry, the power to do justice and reject corruption and injustice (present in a world separated from God - Love as real plagues and, ultimately, assimilated by collective belief as a "normal" way of living).

\section{3. "Power" in a post- patriarchal society}

Power, perceived as freed from the patriarchal perspective and any other deviant form of practicing the discrimination between sexes (man superior to woman) is the power seen as devotion, mercy, compassion, care, empathy towards the poor or the needy, doing good (not accidentally or unconsciously, but always, consciously and voluntarily), the power to heal a hurt soul because of living separated from God, (which does not turn into "being", to assume the embodiment and likelihood with God in man), is the tenderness and comfort for a person's soul (neglected or despised in secular patriarchal orders). It is the power meant to help the weak, the oppressed, the chased or the needy, not as the law of the jungle (the law of the powerful, essentially opposed to the Christian law of loving those round you).

The Christian law does not divide people into categories, but comes to teach mankind to know the truth, to make them realize the existence of heaven and their need to be redeemed, realize that man should re-arrange his position on the Christian axis, of virtues and God's law (the law of loving those around you and God).

In the Holy Spirit Eon, which, among other things, achieves the Great Union between female and male energies, gathering in one unit the buman being separated for five millenniums (female universe/male universe), thus operating more than a reconciliation, operating a monadic re-building of the buman being (rediscovering the beavenly meaning of buman condition), the perverted understanding and practice of female/male energies, on our planet, will be overcome.

In the Holy Spirit Eon, the female energy will be understood in terms of power, but the power will be understood in feminist terms: as giving, (not as exploitation, profit, greed, grab); as care and compassion (not as selfishness, vanity, greed, the type of thinking "I deserve everything, you can die, I don't care); as forgiveness and tenderness (not as revenge, cruelty, mercilessness, a heart of stone, "objective" spirit preached in the patriarchal age, actually perpetuating the

31 The feminine representative of the wisdom, the first spirit created by God and who assisted Him when He created the world. See Book of Solomon's Wisdom, ch.1:6, ch. 7:22, 25, 26, ch. 9:9, ch. 10. Manfred Schmidt-Brabant, Isis-Sophia și Marea Mamă, op. cit., pp. 54-55. 
pattern of patriarchal values); as generosity (not greed, profit, selfishness); as doing good and making peace, promoting non-conflict solutions, promoting empathic methods of communication, useful for developing the spiritual in both sides, for assuming the lessons of life (not promoting war, praising the necessity of conflicts or their inevitability because human nature would be antagonistic, perverted models which generate separations).

Also, in feminist terms, power will be understood by the new human civilizations starting in the $21^{\text {st }}$ century as belping the weak, doing justice, promoting the spirit of justice combined with kindness and mercy ${ }^{32}$ (not blind justice, which in an excess of "objectivity", can produce a paradoxical effect of injustice); as helping the suffering, the wrongly accused, the needy confronted with hardship (practicing the ethical rules from Blessings, of helping those in trouble).

\section{All these will build a new pattern of power, based on an integrated}

perspective (man is the one close to you, not the "other", i.e., "stranger", "enemy"). The human being becomes another face of God, which you should respect. There appears, at the social-political level as well as collective attitude (cultural level), a genuine concern to help the others (who were wrong, did injustice, drifted apart from the Christian law), not to punish, but to make them realize their mistakes, learn their lessons consciously, without anger or bitterness. It is very important that the $21^{\text {st }}$ century human being should accept the mistakes and learn from them so as to be able to evolve spiritually and understand God's love towards all people. Even though, being limited, the human being cannot fully understand, he ought to keep trying to apply the great Christian law of loving the others and God, who is the basis of the entire Eon in which humankind will live and which cannot deny, as he did 2000 years ago, stubbornly perpetuating his patriarchal shell.

Power, in feminist terms, will not be defined or applied as a patriarchal pattern (i.e., in schismatic terms, as male power over female and also as power over the weak, the needy or the defenceless).

\footnotetext{
32 Mary Daly has the same opinion, as quoted by Mihaela Miroiu in Convenio. Despre natură, femei si morală, Ed. Alternative, Bucharest, 1996, p. 146 (referring to the feminine virtue of prudence, defined as "practical wisdom" of "finding right reasons for doing something, keeping the balance between the excessive shortage and over demanding"; it is not confused with "refrain from social conventions", i.e., here justice is imagined as having three open eyes, not two blind eyes; justice, in Mary Daly's view, does not deal with punishing the wrong-doers, but with their education to respect and protect feminist values in society and also helping the oppressed to free themselves from what keeps them in that condition). The virtue of courage is also mentioned (from Latin cor/heart) as a "border virtue between reason and feeling", through which "becoming aware of the feminine power can be done by counting on your heart rather than exclusively on intelligence", as in the schismatic male values (separated from everything that leads to the female universe).
} 
Moreover, it must be said that beginning with the $21^{\text {st }}$ century, as far as human societies and their civilizations are concerned, the feminist power will look for achieving and becoming aware of the interdependence with the male (universe, values, energy, physical being), but with a post-patriarchal male.

Power, in feminist terms, as it will be applied from the $21^{\text {st }}$ century on, will be the power operating gently, not using cruelty, terror, lie, blackmail, plot, robbery or exploitation of people and areas (as it was the case during the long patriarchal ages).

From the feminist perspective, power will be a continuous exercise of kindness, mercy as well as justice. But justice will not be taken for partiality (as the ruler pleases) or cruelty and will not be vicious (corruption, blackmail). It is humane justice, after the Christian model, combined with mercy, not the objective one (pretending to be objective, in fact, applied in the patriarchal age as the man- monarch's justice or mostly/exclusively male elite on behalf of the community or as a "divine" right in a discriminating interpretation against the female status. There is not blind justice - during some periods of collective reign, such as the democratic one, in fact, also elitist- nor is a biased vicious justice (in fact, becoming the justice of the almighty, i.e. the law of the jungle, just the opposite of the Christian law, by reversing the values in the societies separated from God and the Christian law) ${ }^{33}$.

Power, in the New Eon (which will lead to the fall of the patriarchal systems based on organized violence as foundation for the society to function) will be supported by spirituality, that is, by resuming and becoming again aware of the connection man - God. This connection has been either cut off or undermined, becoming too formal, suffering deep disruptions or being misshaped in the patriarchal sense (and used as an argument for the supremacy of male over female).

In the Holy Spirit Eon, all newly-built civilizations will have this new perspective on powver (as organized Kindness, not as organized violence) since there will not start from a perverted principle (of the "wolf" condition, of "natural inherent to human nature" conflict as this altered perspective is based on the separation of man from God, God denial, sacrifice denial - namely, Christian love, is based on selfishness and/or on the idea that man was an animal, a prey one, a wolf) ${ }^{34}$.

The feminist perspective on power is completely different from this perspective which was dominant over the long row of dark ages. People, societies, civilizations, political entities will no longer be organized on the perverted male criteria (violence, domination, terror, robbery, aggression, conquest, exploitation,

\footnotetext{
${ }^{33}$ Law whose content was not liked by the patriarchal spirit and which was not applied correctly, being purely formal in the elitist patriarchal societies(religious elitist societies), when it was not totally denied, as everything that came from God, a hand held out for man to reach (materialistic elitist societies)

34 The hobbesian pattern, based on the"inevitable" status of violence between humans.
} 
cruelty, arbitrary, but irresponsible thinking), on the contrary, on the criteria of rediscovering pure, initial meanings of the two energies (co-creation, life-protection, responsibility, commitment, kindness, co-operation, empathy, participation, dialogue, strategy, education, discouraging violence and decadence, promoted as "freedom" during different periods of the patriarchal age).

\section{Conclusions}

Although the New Eon is founded on the cooperation of the two energies (understood as: universes, values, human being level or societies), not on the ancient ranking perception, reversed this time (domination of the female over male, getting- even age), we would rather name power in feminist terms, mainly referring it to the Christian law, which from the perspective of the perverted male (having become deadly, destructive, voracious energy) appears as a law of weakness that cannot last ${ }^{35}$ (although love is the most powerful force of the entire Divine Creation, as this Creation cannot be considered, nor can it operate apart from God-Love. Furthermore, we support the idea of an Eon of the Holy Spirit, Who chose a feminine embodiment on this Earth, among other things, to put an end to the schismatic, ranking, unjust perception of sexes ("the superiority" of male over female, "The Absolute Man" mistaken for God).

In this Eon there will apply and develop the right patterns of relating man to God: God as Spirit (where there is freedom, where the initial human condition can be regained) and God - Love (as opposed to the patriarchal pattern of maintaining control over a schismatic system of terror, domination and formality, of God-Fear). But God has and rules His Kingdom in love, not in fear, opposing the favourite pattern of the discriminating, abusive, tyrannical "Absolute Master" stubbornly applied by the patriarchal elites over the millenniums. God is love, forgiveness, justice as well as comforting mercy, since all virtues spring from Him. Fear, domination, terror, unjust punishment, cruelty or nonsense are not to be found in God's Being ${ }^{36}$. This is what mankind must understand from the $21^{\text {st }}$ century on, when, in the Holy Spirit Eon, people will have to reconsider their relation to God in terms of the Holy Spirit (Spirit, Truth, Love), not in elitist patriarchal terms, interested in preserving the remains of an outdated, pseudo-buman system.

Re-establishing the buman being (as monadic being, reunited in the two persons, female/male, interconnected through love, resembling the interrelation among the Holy Three ${ }^{37}$, hence recapturing the sacred meaning of "the embodiment and likelihood of God" in man) in their blessed condition, after being

\footnotetext{
${ }^{35}$ David C. Korten, op. cit., p. 88-90.

${ }^{36}$ David C. Korten, op. cit., p.217.

${ }^{37}$ Arhim. Ilie Cleopa, Călăuză în credința ortodoxă, Ed. Episcopiei Dunărea de Jos, Galați, 1991, pp. 58-59.
} 
lost in the false, falling history (which does not define them as "the embodiment and likelihood of God") requires, of course, a return of the woman to berself $f^{8}$ (to seek and find her true self again in order to fully understand the female energy in its pure, bright meaning, but also complementary to male energy).

However, if the feminine effort were limited to that, it would certainly be a waste of time. The feminine self, once re-discovered, cannot fully assert itself in separation and hostility towards the male energy (together with the male values and universe - taking into account only the bright, co-operative ones, as they are understood by the cosmic-divine law of love). The feminine self would be trapped in isolation, in defining itself in terms of difference-hostility to the male self, which would lead to dark ages of female domination (a kind of matriarchal pattern of female terror over a chased, frightened, exploited, cast away, rightless male, following the patriarchal pattern). This would mean repeating the fall in the false history and a dual, hostile perspective (face turned away from face), which would not be a feature of the Holy Spirit Eon.

Therefore, after re-discovering the true feminine self (pure, bright, loving, glamorous energy) opening up towards the other is essential. Meanwhile, "the other" has also evolved and accomplished his inner reform in the Holy Spirit Eon.

It is important, at the beginning of the New Eon, that women understand their power and seize to see themselves in terms of the elitist patriarchal pattern (a group of men having the monopoly of defining the concepts and strategies on which that system was built and consolidated). The feminist powver, in our opinion, has freed from the norms, rules and definitions established by the patriarchal elites (in various fields) regarding the feminine/ feminine universe/ feminine values/ the woman in herself.

\section{REFERENCES}

Biblia (2002). Bucureşti: Ed. Institutului Biblic şi de Misiune al BOR.

Cleopa, Ilie, Arhim. (1991). Călăuحă in credinţa ortodoxă. Galați: Ed. Episcopiei Dunărea de Jos.

Credinţa Ortodoxă (2007). Iaşi:Trinitas, Ed. Mitropoliei Moldovei şi Bucovinei.

Korten, David C. (2007). Marea Cotitură. De la Imperiu la Comunitatea terestră, trad. de Mihnea Columbeanu. Prahova: Ed. Antet.

Miroiu, Mihaela (1995). Gândul umbrei, Eseuri feministe în filozofia contemporană. Bucureşti:Ed. Alternative

Miroiu, Mihaela (1996). Convenio. Despre natură, femei şi morală. Bucureşti: Ed. Alternative.

Mureşan, Vianu (2006). Simbolul. Icoana. Fața. Cluj-Napoca: Ed. Eikon.

${ }^{38}$ Mihaela Miroiu, Gândul umbrei, op. cit., pg. 149. 
Schmidt-Brabant, Manfred (2011). Isis-Sophia și Marea Mamă, in Femininul arbetipal în curentul misterial al umanității. Către o nouă cultură a familiei (Schmidt-Brabant, Manfred; Sease Virginia, coord.), trad. Daniela Lazăr. Bucureşti: Ed. Univers Enciclopedic Gold, Trade. 